\title{
Angiopoietin-1 Receptor
}

National Cancer Institute

\section{Source}

National Cancer Institute. Angiopoietin-1 Receptor. NCI Thesaurus. Code C18488.

Angiopoietin-1 receptor (1124 aa, $126 \mathrm{kDa}$ ) is encoded by the human TEK gene. This protein is involved in angiopoietin signaling, tyrosine phosphorylation and endothelial cell maintenance. 